\title{
Protein co-products and by-products of the biodiesel industry for ruminants feeding
}

\author{
Ricardo Andrés Botero Carrera ${ }^{1}$, Cristina Mattos Veloso ${ }^{2}$, Leonardo Sidney Knupp ${ }^{1}$, \\ Alcy Heleno de Souza Júnior ${ }^{1}$, Edenio Detmann², Rogério de Paula Lana ${ }^{2}$ \\ 1 Programa de Pós-graduação em Zootecnia - Departamento de Zootecnia/Universidade Federal de Viçosa - Viçosa, MG, Brasil.
2 Departamento de Zootecnia/Universidade Federal de Viçosa - Viçosa, MG, Brasil.
}

ABSTRACT - The objective of the experiment was to classify 20 protein co-products and by-products of the biodiesel industry with potential to use in ruminant feeding. The meals evaluated were: cottonseed, canudo-de-pito, crambe, sunflower, castor-oil seeds detoxified with calcium, non-detoxified castor-oil seeds and soybean; and the cakes were: cottonseed, peanut, babassu, crambe, palm oil, sunflower, licuri, macauba seeds, non-detoxified castor-oil seeds, turnip and jatropha. The samples were quantified to determine dry matter (DM), organic matter (OM), crude protein (CP), ether extract (EE), neutral detergent fiber corrected for ash and protein (NDFap), non-fiber carbohydrates (NFC), acid detergent fiber corrected for ash and protein (ADFap), lignin, cutin and starch levels. The CP profile was characterized in fractions A, B1, B2, B3 and C. The in vitro dry matter digestibility (IVDMD), in vitro neutral detergent fiber digestibility (IVNDFD), rumen degradable and undegradable protein, intestinal digestibility, indigestible neutral detergent fiber and undegradable neutral detergent insoluble protein were evaluated. The OM, CP, EE, NDFap, NFC, ADFap, lignin, cutin and starch contents varied from 81.95 to $95.41 \%, 18.92$ to $57.75 \%, 0.56$ to $18.40 \%, 10.13$ to $62.30 \%$, 3.89 to $27.88 \%, 6.15$ to $36.86 \%, 1.19$ to $5.04 \%, 0$ to $17.87 \%$ and 0.68 to $14.50 \%$, respectively. The values of fractions A, B1, B2, B3 and C ranged from 5.40 to $43.31 \%, 0.08$ to $37.63 \%, 16.75$ to $79.39 \%$, 1.86 to $59.15 \%$ and 0.60 to $11.47 \%$, respectively. Concentrations of IVDMD, IVNDFD, rumen-degradable and undegradable protein, intestinal digestibility, indigestible NDF and undegradable neutral detergent insoluble protein ranged from 31.00 to $95.92 \%, 55.04$ to $97.74 \%, 41.06$ to $97.61 \%, 2.39$ to $58.94,9.27$ to $94.26 \%, 1.05$ to $40.80 \%$ and 0.29 to $2.92 \%$, respectively. Some of these products can replace soybean meal, specially the Macauba seeds cake, cottonseed meal and peanut and turnip cakes based on digestive characteristics.

Key Words: bromatology, chemical composition, digestive traits, in vitro digestibility

\section{Introduction}

The total world demand for primary energy reaches 11.4 billion tons of oil equivalents per year (IEA, 2006). The increasing demand for fuels, associated to the growing environmental care, has been stimulating the search for alternative energy sources in Brazil and the whole world. Among these options, it is important to point out liquid biofuels, which represent $1.9 \%$ of the whole bioenergy produced; also, in the transport sector in the year 2005, biofuels supplied $0.9 \%$ of the entire fuel consumption (FAO, 2008).

The stimulation of biodiesel production, also, constitutes a governmental goal to reduce the dependency on external non-renewable fuel sources in Brazil. The use of renewable sources is not only appreciated through the environmental point of view, but it also plays an essential role in the establishing of family agricultural programs.
Extraction makes it possible to achieve a high number of by-products and co-products, which, without a proper destination, can generate a series of problems related to their accumulation in the environment. The production of oilseed cakes and meals corresponding to the biodiesel produced in 2008 can be estimated in 3.7 million tons; considering the same proportions, Brazil will be able to produce around 8.9 million tons of cakes in 2013 (Abdalla et al., 2008). Their composition varies according to the types of species, cultivation and extraction of the oilseeds. The cakes are obtained through mechanical extraction and the meals through extraction with solvent.

Many of these products can be used as feed for ruminants. Ruminants are capable of turning materials that are not useful for humans into animal origin products of high biological value, due to the microbial fermentative process that takes place in their gastrointestinal tracit. The use of these products can also reduce animal feeding costs. 
Inside this specific context, the objective of this study was to assess chemical and digestive characteristics of protein co-products and by-products in the biodiesel industry with potential use as ruminant feeding.

\section{Material and Methods}

The experiment was conducted at the facilities of the Animal Nutrition Laboratory at Universidade Federal de Viçosa, at the Animal Science Department. Twenty cake and seed samples were evaluated, each one corresponding to protein co-products and by-products originated from the biodiesel industry in different parts of the country that presented potential use as ruminant feeding. These coproducts and by-products were: cottonseed meal and cake (Gossypium spp. L.); two peanut cakes (Arachis hypogaea); babassu cake (Orbignya speciosa); canudo-de-pito meal (Mabea fistulifera Mart); crambe meal and cake (Crambe abyssinica); palm oil cake (Elaeis guineensis); sunflower meal and cake (Helianthus annuus); licuri cake (Syagrus coronata); macauba seeds cake (Acrocomia aculeata); castor-oil seeds meal detoxified with calcium and nondetoxified (Ricinus communis); non-detoxified castor-oil seeds cake; turnip cake (Raphanus sativus); two jatropha cakes (Jatropha curcas); and soybean meal (Glycine max). The soybean meal sample was used as a reference for the evaluation of the other material used.

The amounts of dry matter (DM), ash, crude protein (CP), neutral detergent fiber (NDF), acid detergent fiber (ADF), lignin (potassium permanganate method) and cutin were quantified according to the methods described by Silva \& Queiroz (2002). In order to quantify the amounts of NDF and ADF corrected for ash and protein (NDFap and ADFap, respectively), the concentrations of neutral detergent insoluble protein (NDIP), acid detergent insoluble protein (ADIP), neutral detergent insoluble ash (NDIA) and acid detergent insoluble ash (ADIA), were evaluated also according to the methods described by Silva \& Queiroz (2002).

In order to evaluate the amount of ether extract (EE), coproducts and the by-products were placed into XT4 (Ankom ${ }^{\circledR}$ ) bags and subjected to extraction by the AOCS (2009) official high temperature method, using XT15 $\left(\right.$ Ankom ${ }^{\circledR}$ ) extractor.

The formula (Detmann \&Valadares Filho, 2010) NFC = $\mathrm{OM}-(\mathrm{CP}+\mathrm{EE}+\mathrm{NDFap})$ was used to calculate non-fiber carbohydrates (NFC).

To quantify the starch levels in the material, the samples were sent to the Animal Nutrition Laboratory of the
Veterinary Medicine School in Universidade Federal de Minas Gerais. The quantification of the starch levels by the enzymatic technique was done through modified amyloglucosidase $-\alpha$-amylase (McCleary et al., 1997).

Samples ground to $1 \mathrm{~mm}$ were used for the evaluation of the in vitro dry matter digestibility (IVDMD) and the in vitro neutral detergent fiber digestibility (IVNDFD). For ruminal incubation and quantification of the rumen degradable protein, rumen undegradable protein, intestinal protein digestibility, indigestible NDF (iNDF) and undegradable neutral detergent insoluble protein, the samples used were ground to $2 \mathrm{~mm}$.

The IVDMD was evaluated according to the methodology proposed by Tilley \& Terry (1963), in two different fermentation stages, for 48 hours of incubation. After obtaining the residues of the IVDMD, the residues of NDF were evaluated in order to quantify the IVNDFD. For the inoculation, a ruminal liquid obtained from a noncastrated and fistulated bovine male, fed with grass and supplemented with $2 \mathrm{~kg}$ of feed a day ( $20 \% \mathrm{CP})$, was used.

Intestinal digestibility was analyzed through the three stages method according to the method described by Calsamiglia \& Stern (1995). Samples in nylon bags were incubated for 16 hours inside a non-castrated male bovine, fed with grass and supplemented with $2 \mathrm{~kg}$ of feed a day, keeping the proportions of $20-25 \mathrm{mg}$ of sample/ $\mathrm{cm}^{2}$. After ruminal incubation, the bags were washed in running water up to total cleaning and placed in a forced ventilation oven, under a temperature of $60^{\circ} \mathrm{C}$, for 48 hours.

Later, the nitrogen $(\mathrm{N})$ present in the residue (Silva \& Queiroz, 2002) was quantified. Aliquots containing $15 \mathrm{mg}$ of $\mathrm{N}$ were placed in $50 \mathrm{~mL}$ centrifugal tubes. The tubes were then incubated with $10 \mathrm{~mL}$ of a $0.1-\mathrm{N}$ solution of $\mathrm{HCI}$, containing $1 \mathrm{~g} / \mathrm{L}$ of pepsin ( $\mathrm{pH}=1.9$ ), and put under agitation to a speed of $40 \mathrm{rpm}$, for 1 hour at a temperature of $38^{\circ} \mathrm{C}$. Next, $0.5 \mathrm{~mL}$ of $1 \mathrm{~N}$ of a $\mathrm{NaOH}$ solution was added, in order to neutralize acidity, and $13.5 \mathrm{~mL}$ of pancreatin solution, containing: $0.5 \mathrm{M}$ of $\mathrm{KH}_{2} \mathrm{PO}_{4}(\mathrm{pH}=7.8)$ solution, $50 \mathrm{ppm}$ of thymol, to prevent microbial development, and $3 \mathrm{~g} / \mathrm{L}$ of pancreatin. These were kept under agitation for 24 hours at a speed of $40 \mathrm{rpm}$ and temperature of $38^{\circ} \mathrm{C}$. At the end of the digestion, $3 \mathrm{~mL}$ of a trichloroacetic acid (TCA) $100 \%$ (weigh/volume) solution was added, in order to stop enzymatic activity and to precipitate non-digested protein. The samples were centrifuged for 15 minutes at $10.000 \times \mathrm{g}$ and the supernatant of the tubes was used for residual $\mathrm{N}$ evaluation through the Kjeldahl method (Silva \& Queiroz, 2002). Intestinal digestibility of the rumen-undegradable protein was calculated as the ratio between the amount of 
CP digested after pepsin incubation and the amount of incubated protein.

The proportion of rumen-degradable and undegradable protein in the $\mathrm{CP}$ was estimated through the relation between the amount of CP incubated in the rumen, and the nondegraded rumen protein after 16 hours of animal incubation. The digestible rumen-undegradable protein was calculated through the multiplication of the rumen-undegradable protein by the protein intestinal digestibility, which is determined by the three-stage method.

The estimate of the indigestible neutral detergent fiber was made through in situ incubation procedures for 240 hours, inside a non-castrated fistulated bovine male, fed with grass and supplemented with $2 \mathrm{~kg}$ concentrate/day, following the procedures described by Casali et al. (2008) and using non-woven fabric $\left(100 \mathrm{~g} / \mathrm{m}^{2}\right)$ bags as incubation containers. The residue of the indigestible NDF was then used to estimate undegradable neutral detergent insoluble protein, as described by Detmann et al. (2004) and defined as the approximate to the parametrical value of the cellular walls undegradable protein.

For the quantification of non-protein nitrogen (NPN, fraction A) through the trichloroacetic acid method (TCA) and the true soluble protein (fraction B1), obtained by soluble fraction in borate-phosphate tampon (fraction $\mathrm{A}+\mathrm{B} 1$ ) minus the TCA soluble fraction (fraction $A$ ), the methods followed were the ones described by Licitra et al. (1996).

The division of the protein fractions was related to the speed at which protein is degraded by enzymes. The boratephosphate soluble protein is known as fraction A (NPN) + $\mathrm{B} 1$ (true soluble protein). Fraction B1 is calculated by the subtraction of the NPN fraction, from fraction A+B1 (Licitra et al., 1996). B1 is easily degraded and converted into ammonia in the rumen (Sniffen et al., 1992).

Fraction C (indigestible fraction) was quantified as the undegradable neutral detergent insoluble protein. Fraction B3 is represented by the extensins, which are linking proteins from the cellular walls that present a slow degradation rate and, because of that, are mainly digested in the intestines (Cabral et al., 2004). The value of fraction B3 was obtained by the difference between neutral detergent insoluble protein and undegradable neutral detergent insoluble protein.

Fraction B2 presents variable fermentation. One of its parts is fermented in the rumen and the other part escapes to the small intestines. The destination of fraction B2 depends on the rates of digestion and passage (Sniffen et al., 1992). Fraction B2 was calculated by the difference between the total CP levels minus fractions A, B1, B3 and C.
The difference in nutritional value, based on discriminatory variables between the groups, was estimated by grouping analysis, using the average euclidian distance along with standardized variables and the grouping methods by optimization (Tocher method). All statistical analyses were according to the software SAEG (Sistema para Análises Estatísticas, version 9.1).

\section{Results and Discussion}

The concentrations of DM are considered excellent for storage and likely to be conserved for a long period of time since the lower water level decreases microbial activity (Gomes, 2007).

It is possible to observe that the OM in the feedstuff ranged from 81.95 to $95.41 \%$ in the detoxified castor-oil seeds meal and the licuri cake, respectively. Concentrations similar to the ones found in this research were observed by Silva et al. (2008b) in soybean meal and jatropha cakes (92.90 and $93.60 \%$, respectively).

The concentrations of CP ranged from 18.92 to $57.75 \%$, for the licuri cake and the canudo-de-pito meal, respectively. The concentrations of CP in the detoxified castor-oil seeds meal, turnip cake, jatropha cake I, palm oil cake, soybean meal, crambe cake and turnip cake II are similar to the ones observed in literature by Oliveira et al. (2004), Neiva Júnior et al. (2007), Arieta et al. (2009), Menezes et al. (2009) and Souza et al. (2009). The concentrations of CP in sunflower, cottonseed and non-detoxified castor-oil seeds cakes, and in the cottonseed meal differed from the ones obtained by Neiva Júnior et al. (2007), Silva et al. (2008b) and Arieta et al. (2009), respectively. They observed respective levels of $31.26 ; 35.00 ; 26.50$ and $27.58 \%$. This variation in the results seem to be due to the difference in oil extraction methods in the industry and consequently in the non-standardized meal and cake production, available for cattle raising.

The concentrations of EE ranged from 0.56 to $18.40 \%$ for crambe meal and cake, respectively. Similar levels to some co-products and by-products are obtained in the literature: Arieta et al. (2009) found EE levels of 5.73 and $13.24 \%$ in the turnip and palm oil cakes, respectively.

The concentrations of NDFap were 10.13 and $62.30 \%$ in canudo-de-pito meal and the babassu cake, respectively. The level of NDFap in cottonseed cake is similar to the one mentioned by Silva et al. (2008b); this level was $46.30 \%$. The sunflower meal level of $21.8 \%$ presented in the research of Marcondes et al. (2009) is rather lower than the one observed in Table 1. Neutral detergent fiber directly influences voluntary consumption and nutritional value, as a result of 
Table 1 - Chemical composition of feedstuffs

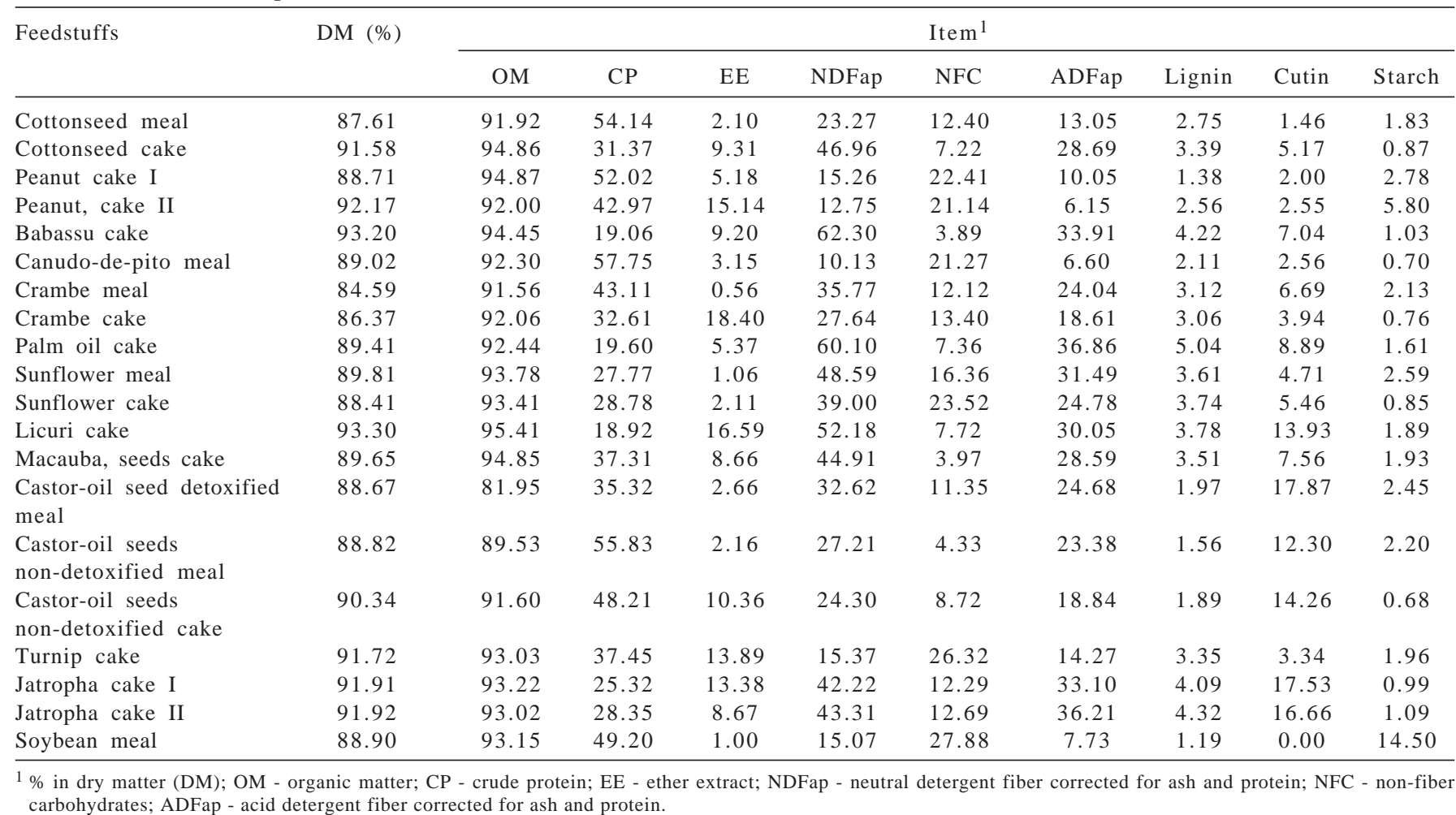

its insolubility in neutral conditions, as the rumen, and in general, due to its slow utilization by ruminal microorganisms, in comparison with the components of the other feedstuffs (Detmann et al., 2008b).

Regarding NFC, concentrations ranged from 3.89 to $27.88 \%$, for babassu cake and soybean meal, respectively. In the literature, different concentrations were found in sunflower cake and soybean meal: 47.01 and 36.14\%, respectively, reported by Marcondes et al. (2009).

The concentrations of ADF corrected for nitrogen and protein (ADFap) ranged from 6.15 to $36.86 \%$ for peanut cake II and palm oil cake, respectively. Concentrations of ADFap different from the observed in this research were reported by Marcondes et al. (2009), who obtained levels of 15.64 and $4.29 \%$ in sunflower and soybean meals, respectively.

Lignin concentrations ranged from 1.19 to $5.04 \%$ in soybean meal and babassu cake, respectively. In palm oil and babassu cakes and in the detoxified castor-oil seeds meal, the levels obtained by Moreira et al. (2003), Gomes (2007) and Silva et al. (2008a) were 24.60, $17.90 \%$ and $12.24 \%$, respectively. This suggests that the feedstuffs analyzed by these authors were contaminated by cutin, possibly because of the lignin analysis method.

Cutin concentrations ranged from 0 to $17.87 \%$ in soybean and detoxified castor-oil seeds meals, respectively. Cutin is presented as a barrier to ruminal microorganisms (Van Soest, 1994).
Starch levels ranged from 0.68 to $14.50 \%$ in the nondetoxified castor-oil seeds cake and soybean meal, respectively. The level of starch in soybean meal was a different number from that reported by Valadares Filho et al. (2006), of 8.89\%. The difference between the starch level numbers could be due to the variation in the results to which the enzymatic methods can be subjected (Saliba, 2009).

The first group (GI) was formed by 14 feedstuffs; the second group (GII) by four feedstuffs; and the groups three (GIII) and four (GIV) by one feedstuff each (Table 2). The Tocher method, adopted in this research, leads to group establishment so that there is homogeneity inside the group and heterogeneity between them. The variable of greatest contribution for the proposed grouping was CP (27.40\%), followed by EE (14.20\%), NDFap (13.70\%), NFC (12.10\%), lignin (11.60\%), OM (11.10\%), cutin (4.74\%), starch (3.16\%) and, lastly, ADFap (2.11\%).

The concentration of CP was found to be the main characteristic separating the groups, basically in: GI and GIII, they presented the lowest levels of CP, around 34\%. The ones with the highest CP levels were GII and GIV, around $50 \%$. It was verified that GI and GIII, still containing a similar amount of $\mathrm{CP}$, were separated due to the fact that GIII presents lower OM levels than GI (81.95 and 93.26\%, respectively).

Another difference between these two groups was that GI presented an $8.55 \%$ concentration of EE, compared with 
Table 2 - Feedstuff groups based on chemical composition

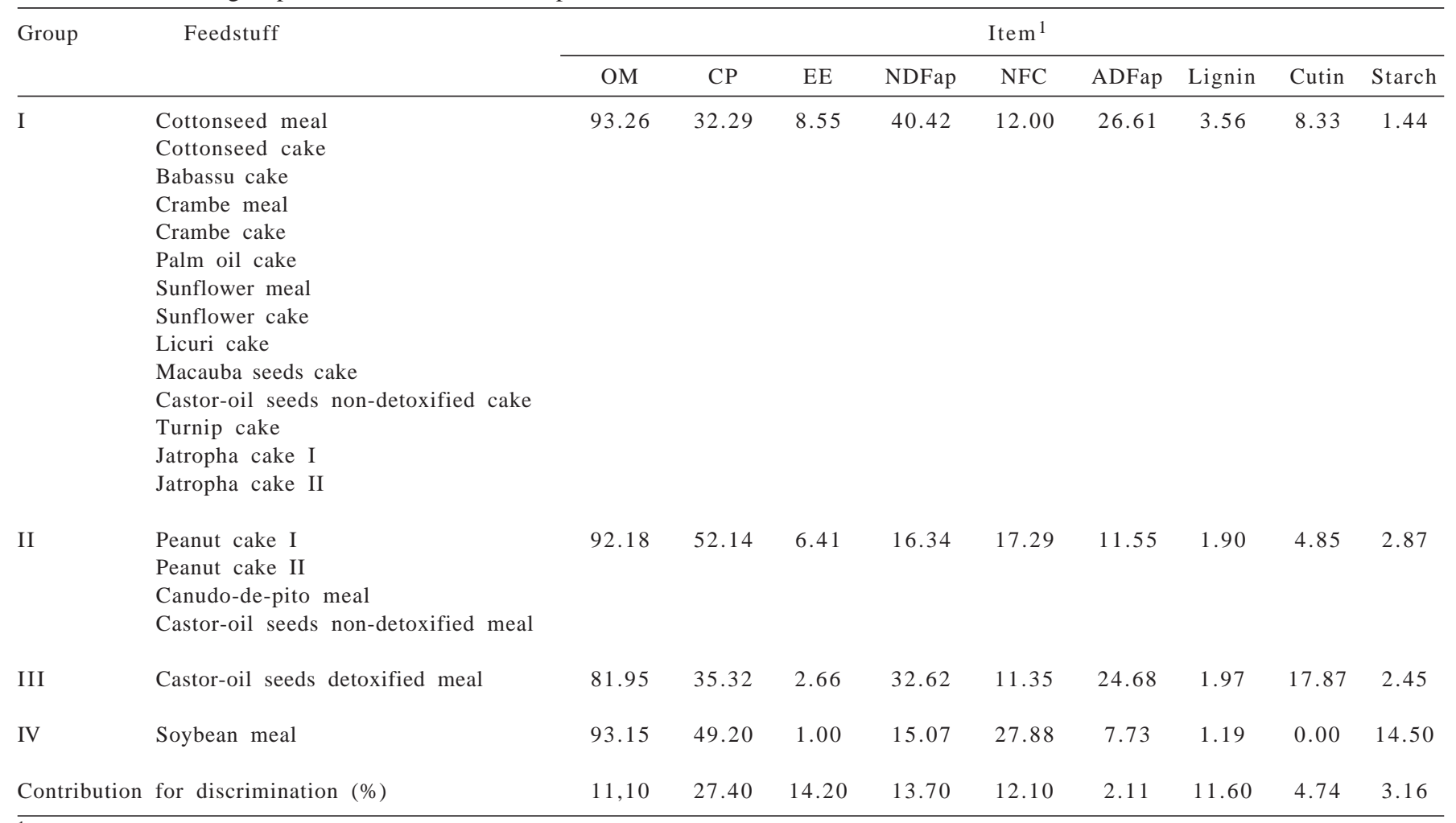

$1 \%$ mean values based on organic matter; OM - organic matter; CP - crude protein; EE - ether extract; NDFap - neutral detergent fiber corrected for ash and protein; NFC - non-fiber carbohydrates; ADFap - acid detergent fiber corrected for ash and protein.

2.66\% in GIII. In GII and GIV, the average concentrations of EE were 6.41 and $1.00 \%$, respectively.

The concentration of NDFap was an important characteristic for feedstuffs clustering. GI and GIII presented elevated NDFap levels of 40.42 and $32.62 \%$, respectively. On the other hand, GII and GIV presented NDFap levels of 16.34 and $15.07 \%$, respectively.

The concentration of NFC, like the one observed for CP, was smaller than the ones in GI and GIII, which were 12.00 and $11.35 \%$, respectively. GII and GIV presented more elevated NFC levels: 17.29 and $27.88 \%$, respectively.

Another significant difference between GI and GIII was the amount of cutin. The former had 8.33 and the latter, $17.87 \%$. GIII was the group that presented the highest cutin level; this high cutin level separates GIII and GI completely, although they remain similar in other items. GII and GIV presented largely different cutin levels although they had similar levels of some of the components. GIV, which was exclusively formed by soybean meal, did not present cutin and GIII presented an average level of $4.85 \%$.

Regarding lignin levels, the highest level was observed in GI (3.56\%); groups II, III and IV presented lignin levels that were below $2 \%$. Regarding starch levels, the highest mark was in GIV (14.50\%). This number separates GIV from the other three groups.
Soybean meal (GIV) presented the best chemical composition; however, GII presented similar chemical characteristics, with higher EE levels and lower starch levels than GIV.

The division of protein levels (Table 3) was done according to the Cornell Net Carbohydrate and Protein System (Fox et al., 2004), and according to suggestion of Detmann et al. (2004), fraction C was modified.

The heating of the material generates a general reduction in cytoplasmatic protein through denaturing. The degree of the solubility reduction depends on circumstances, more specifically temperature and or, the time of heating applied to the material (Van Soest, 1994). Therefore, protein fractioning allows a more precise use of nutrients in animal feeding, which also enables a prediction regarding protein digestibility on the feedstuff with predictive models and equations.

Fraction A, or NPN, ranged from 5.40 to $43.31 \%$ for soybean meal and crambe cake, respectively. Levels of fraction B1 ranged from 0.08 to $37.63 \%$ in non-detoxified castor-oil seeds meal and in peanut cake I, respectively. Levels of fraction B2 were between 16.75 and $79.39 \%$ for palm oil cake and soybean meal, respectively. Levels of fraction B3 ranged from 1.86 to $59.15 \%$, corresponding to turnip and palm oil cake, respectively. Protein supplements have low levels of fraction B3, but, on the other hand, co- 
Table 3 - Crude protein chemical profile

\begin{tabular}{|c|c|c|c|c|c|}
\hline \multirow[t]{2}{*}{ Feedstuff } & \multicolumn{5}{|c|}{ Fraction $^{1}$} \\
\hline & NPN & B1 & B2 & B3 & $\mathrm{C}$ \\
\hline Cottonseed meal & 9.61 & 1.61 & 76.40 & 11.23 & 1.15 \\
\hline Cottonseed cake & 12.01 & 1.39 & 77.97 & 5.31 & 3.32 \\
\hline Peanut cake I & 24.63 & 37.63 & 34.62 & 2.38 & 0.74 \\
\hline Peanut cake II & 20.74 & 36.04 & 38.04 & 4.32 & 0.87 \\
\hline Babassu cake & 9.02 & 0.19 & 41.32 & 41.51 & 7.96 \\
\hline Canudo-de-pito meal & 8.11 & 13.76 & 74.26 & 2.00 & 1.88 \\
\hline Crambe meal & 30.01 & 1.92 & 55.47 & 9.20 & 3.40 \\
\hline Crambe cake & 43.31 & 3.60 & 46.72 & 3.14 & 3.22 \\
\hline Palm oil cake & 8.53 & 4.10 & 16.75 & 59.15 & 11.47 \\
\hline Sunflower meal & 11.65 & 23.83 & 50.73 & 11.04 & 2.76 \\
\hline Sunflower cake & 9.18 & 1.36 & 65.70 & 20.77 & 2.98 \\
\hline Licuri cake & 18.68 & 3.48 & 61.57 & 11.53 & 4.74 \\
\hline Macauba seeds cake & 13.68 & 15.89 & 65.17 & 2.90 & 2.37 \\
\hline Castor-oil seeds detoxified meal & 21.42 & 0.20 & 65.56 & 4.56 & 8.26 \\
\hline Castor-oil seeds non-detoxified meal & 18.13 & 0.08 & 71.65 & 7.01 & 3.12 \\
\hline Castor-oil seeds non-detoxified cake & 26.78 & 3.36 & 64.11 & 2.93 & 2.81 \\
\hline Turnip cake & 40.08 & 3.40 & 50.81 & 1.86 & 3.84 \\
\hline Jatropha cake I & 12.97 & 1.38 & 76.70 & 4.06 & 4.89 \\
\hline Jatropha cake II & 12.71 & 12.49 & 64.02 & 5.39 & 5.39 \\
\hline Soybean meal & 5.40 & 0.15 & 79.39 & 14.47 & 0.60 \\
\hline
\end{tabular}

products and by-products have a significant amount of this fraction (Krishnamoorthy et al., 1982).

Fraction C presented soybean meal level of 0.60 and palm oil cake, of $11.47 \%$. This fraction represents the indigestible part of crude protein, therefore, not available for the animal.

Fractioning $\mathrm{CP}$ is important because the consideration of CP in feedstuff, as a homogeneous entity, could lead to distortions on the estimates of the fraction that is apparently digestible regarding chemical composition of feedstuffs produced in tropical conditions. This way, partitioning total $\mathrm{CP}$ would lead to a more accurate estimate of the dietetic levels of apparently digestible CP (Detmann et al., 2008a).

Four groups were formed and the variable of greater contribution in discrimination was fraction B1 (28.90\%), followed by B2 (22.60\%), B3 (20.00\%), NPN (18.40\%) and fraction C (10.00\%). The first group (GI) was formed by 14 feedstuffs, the second group (GII) by three feedstuffs, the third group (GIII) by two feedstuffs, and the fourth group (GIV) by one feedstuff (Table 4). It is possible to observe that GIV levels of fraction B2 and NPN were similar to the ones in GI; however, the levels of fraction B1 were largely different between the two groups and that brought them apart. Also, GI presented lower and higher fraction $\mathrm{C}$ and fraction B3 levels than GIV, respectively. These numbers were 3.12 and $7.27 \%$ in GI and 8.26 and $4.56 \%$ in GIV, respectively.
GII presented NPN levels similar to the ones found in GI; however, fraction B1 was different, with $32.50 \%$ in GII and $4.56 \%$ in GI. There was also difference between the levels of fractions B2, B3 and C for both groups, these values were $66.42,7.27$ and $3.12 \%$ in GI, respectively, and 41.13, 5.91 and $1.45 \%$ in GII, respectively.

GIII presented more protein associated to the fiber, corresponding to fraction B3. Feedstuffs from this group presented the highest levels of NDFap (Table 1).

Excluding babassu and palm oil cake, cakes presented good CP chemical profiles due to the low level of fractions $\mathrm{B} 3$ and $\mathrm{C}$ and, especially, to high proportions of fractions $\mathrm{B} 1$ and $\mathrm{B} 2$, allowing part of this protein to be fermented in the rumen and part to escape to small intestines, resulting in better uses of CP.

In vitro dry matter digestibility ranged from 31.00 to 95.92\% for detoxified castor-oil seeds and soybean meal, respectively (Table 5). Regarding the percentage of IVNDFD, they were between 55.04 and $97.74 \%$ for licuri cake and soybean meal, respectively. Inferior values of IVNDFD are related to higher proportions of indigestible NDF and can be due to higher proportions of peel in some feedstuffs.

The concentration of rumen-degradable protein ranged from 41.06 to $97.61 \%$ for palm oil cake and peanut cake I, respectively. The concentration of rumen-degradable protein in soybean and cottonseed meals differed from the ones reported by Cabral et al. (2001), which were 50.86 and $64.71 \%$, respectively. The CP of peanut cakes I and 
Table 4 - Feedstuff groups based on crude protein profile

\begin{tabular}{|c|c|c|c|c|c|c|}
\hline Group & Feedstuff & \multicolumn{5}{|c|}{ Average concentration ${ }^{1}$} \\
\hline I & $\begin{array}{l}\text { Cottonseed cake } \\
\text { Cottonseed meal } \\
\text { Canudo-de-pito meal } \\
\text { Crambe meal } \\
\text { Crambe cake } \\
\text { Sunflower cake } \\
\text { Licuri cake } \\
\text { Macauba seeds cake } \\
\text { Castor-oil seeds non-detoxified meal } \\
\text { Castor-oil seeds non-detoxified meal } \\
\text { Turnip cake } \\
\text { Jatropha cake I } \\
\text { Jatropha cake II } \\
\text { Soybean meal }\end{array}$ & 18.62 & 4.56 & 66.42 & 7.27 & 3.12 \\
\hline III & $\begin{array}{l}\text { Babassu cake } \\
\text { Palm oil cake }\end{array}$ & 8.77 & 2.15 & 29.03 & 50.33 & 9.71 \\
\hline IV & Castor-oil seeds detoxified meal & 21.42 & 0.20 & 65.56 & 4.56 & 8.26 \\
\hline Contribution to & discrimination (\%) & 18,40 & 28.90 & 22.60 & 20.00 & 10.00 \\
\hline
\end{tabular}

$1 \%$ of crude protein.NPN - non-protein nitrogen.

II, turnip, crambe and non-detoxified castor-oil seeds cakes, in a similar way to the one in cottonseed and canudo-de-pito meals, presented high rumen degradation; this fact deserves special attention when those elements are added to animal feeding. This is because great nitrogen loss can take place in the rumen so there is the necessity of including energy sources of high availability, since microbial synthesis greater efficiency happens when the rates of degradation of protein and carbohydrates are similar (Lana, 2005).

The concentration of rumen-undegradable protein is inversely proportional to the concentration of rumendegradable protein in feedstuffs. As examples of feedstuffs with high concentration of rumen-undegradable protein, one can point out babassu, palm oil, sunflower and licuri cakes and macauba seeds cake.

Regarding the values observed in the intestinal digestibility of the rumen-undegradable protein, the numbers ranged from 9.27 to $94.26 \%$, in canudo-de-pito and soybean meals, respectively. In soybean meal, this number is in accordance to the ones of $89.9 \%$ obtained by Calsamiglia \& Stern (1995), and of $91.86 \%$, by Marcondes et al. (2009). For cottonseed meal, intestinal digestibility percentage close to that obtained in this research was reported by Cabral et al. (2001), which was $53.66 \%$.
Macauba seeds cake also presented high intestinal digestibility, close to the one obtained in soybean meal. This fact can be attributed to the good quality of protein that was retained in the rumen-undegradable protein portion. Peanut cake II, sunflower, licuri and non-detoxified castor-oil seeds cakes presented intestinal digestibility superior to $80 \%$.

Concentrations of digestible rumen-undegradable protein between 0.33 and $53.32 \%$ were obtained in canudode-pito meal and macauba seeds cake, respectively. It is possible to notice that babassu, palm oil, sunflower, licuri and macauba seeds cakes presented digestible rumenundegradable protein concentration superior to the one presented by soybean meal. Rumen-degradable protein and digestible rumen-undegradable protein fractions are of great importance, since diets in which there is excessive CP or rumen-degradable protein might present a certain asynchrony between protein degradation and energy availability in the rumen. On the other hand, diets presenting inadequate amounts of ammonia and rumen-degradable protein limit microbial development and impair the digestion for carbohydrates fiber fraction (Santos, 1999).

Among ruminants, the greatest part of the capacity in providing the energy necessary for animal maintenance or production refers to the way NDF interacts with microbial enzymatic systems which are responsible for NDF 
Table 5 - Digestive characteristics of the feedstuffs

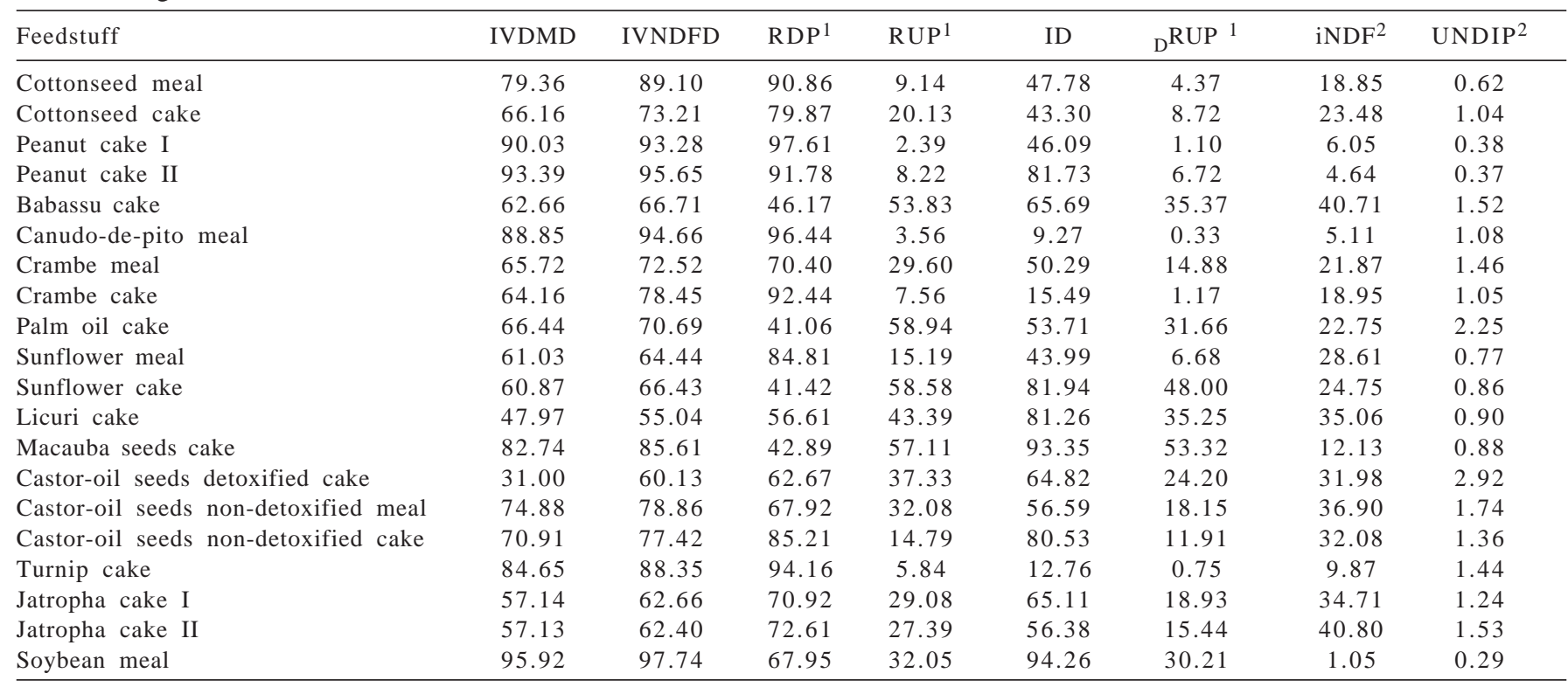

$1 \%$ in CP.

$2 \%$ in dry matter (DM).IVDMD - in vitro DM digestibility; IVNDFD - in vitro neutral detergent fiber digestibility; RDP - rumen degradable protein; RUP - rumen undegradable protein; ID - intestinal digestibility of RUP; ${ }_{D}$ RUP - digestible RUP; iNDF - indigestible neutral detergent fiber; UNDIP - undegradable neutral detergent insoluble protein.

degradation and use (Detmann et al., 2008b). For some times, the digestible NDF fraction constitutes the main energetic fraction in tropical feedstuffs; the indigestible NDF fraction limits consumption due to the gastrointestinal tract-filling factor. The indigestible NDF fraction ranged from 1.05 to $40.80 \%$ for soybean meal and jatropha cake II, respectively. High indigestible NDF concentrations in jatropha cakes I and II, babassu, licuri and non-detoxified castor-oil seeds cakes, and in castor-oil seeds detoxified and non-detoxified meals might be due to the elevated amount of peel found in these feedstuffs. Indigestible NDF concentration in soybean meal was inferior to the one presented by Valadares Filho et al. (2006), who reported a total number of $2.11 \%$.

Regarding undegradable neutral detergent insoluble protein concentration, numbers ranged from 0.29 to $2.92 \%$ in soybean and non-detoxified castor-oil seeds meals, respectively.

Five groups were formed and variables of greater contribution for discrimination were IVNDFD and rumendegradable protein, both with contribution values of $23.20 \%$ (Table 6). Indigestible NDF came second with $13.70 \%$, followed by rumen-undegradable protein (8.95\%), undegradable neutral detergent insoluble protein (8.42\%), IVDMD and intestinal digestibility with the same contribution (7.89\%) and digestible rumen-undegradable protein (6.84\%).

GII and GIV, though with similar values of IVDMD, IVNDFD, indigestible NDF and undegradable neutral detergent insoluble protein, presented different levels of rumen-degradable protein. GII presented higher rumendegradable protein concentration; unlike GIV, the numbers were 95.00 and $55.42 \%$, respectively. GII presented intestinal digestibility and digestible rumen-undegradable protein concentration a lot inferior to the numbers in GIV: 37.46 and $2.22 \%$ in GII and 93.80 and $41.76 \%$ in GIV, respectively.

$\mathrm{GV}$, formed by non-detoxified castor-oil seeds meal only, presented the lowest numbers of IVDMD and IVNDFD and the highest numbers of indigestible NDF and rumenundegradable protein compared with the other groups. GV, however, presented similar IVNDFD to the one presented by GIII, the difference was the fact that intestinal digestibility and digestible rumen-undegradable protein were superior in GIII, these numbers were 64.82 and $24.20 \%$ in GV and 70.65 and $37.57 \%$ in GIII, respectively.

GI and GIII presented similar indigestible NDF and undegradable neutral detergent insoluble protein, although GI had superior IVDMD, IVNDFD and rumen-degradable protein concentration to the ones in GIII: 66.28; 73.23 and $79.45 \%$ in GI, respectively, and 59.49; 64.72 and $46.31 \%$ in GIII, respectively. GI presented inferior intestinal digestibility and digestible rumen-undegradable protein numbers compared with GIII: 51.05 and $11.14 \%$ in GI, respectively, and 70.65 and $37.57 \%$ for GIII, respectively.

It is possible to observe that GIII and GIV presented similar digestible rumen-undegradable protein and rumen digestible protein concentrations. GIV, however presented 
Table 6 - Feedstuff groups based on digestive characteristics

\begin{tabular}{|c|c|c|c|c|c|c|c|c|c|}
\hline Group & Feedstuff & \multicolumn{8}{|c|}{ Average concentration } \\
\hline I & $\begin{array}{l}\text { Cottonseed meal } \\
\text { Cottonseed cake } \\
\text { Crambe meal } \\
\text { Crambe cake } \\
\text { Sunlower meal } \\
\text { Castor-oil seeds non-detoxified meal } \\
\text { Castor-oil seeds non-detoxified cake } \\
\text { Jatropha cake I } \\
\text { Jatropha cake II }\end{array}$ & 66.28 & 73.23 & 79.45 & 20.55 & 51.05 & 11.14 & 28.47 & 1.20 \\
\hline II & $\begin{array}{l}\text { Peanut cake I } \\
\text { Peanut cake II } \\
\text { Canudo-de-pito meal } \\
\text { Turnip cake }\end{array}$ & 89.23 & 92.98 & 95.00 & 5.00 & 37.46 & 2.22 & 6.42 & 0.82 \\
\hline IV & $\begin{array}{l}\text { Macauba seeds cake } \\
\text { Soybean meal }\end{array}$ & 89.33 & 91.67 & 55.42 & 44.58 & 93.80 & 41.76 & 6.59 & 0.59 \\
\hline $\mathrm{V}$ & Castor-oil seeds detoxified meal & 31.00 & 60.13 & 62.67 & 37.33 & 64.82 & 24.20 & 31.98 & 2.92 \\
\hline Contril & discrimination (\%) & 7,89 & 23.20 & 23.20 & 8.95 & 7.89 & 6.84 & 13.70 & 8.42 \\
\hline
\end{tabular}

$1 \%$ in crude protein (CP). ${ }^{2} \%$ in dry matter (DM).IVDMD - in vitro DM digestibility; IVNDFD - in vitro NDF digestibility; RDP - rumen degradable protein; RUP - rumen undegradable protein; ID - intestinal digestibility of RUP; ${ }_{D}$ RUP - digestible RUP; iNDF - indigestible neutral detergent fiber; UNDIP - undegradable neutral detergent insoluble protein.

higher IVDMD and IVNDFD, which were 89.33 and $91.67 \%$ in GIV, and 59.49 and $64.72 \%$ in GIII, respectively. GIV presented rather inferior indigestible NDF and undegradable neutral detergent insoluble protein concentrations, in GIV the numbers were 6.59 and $0.59 \%$, and in GIII, the numbers were 30.82 and $1.38 \%$, respectively.

According to biological characteristics of the feedstuffs, GIV had the best characteristics due to high IVNDFD and intestinal digestibility and having great proportion of rumen-degradable protein and rumen-undegradable protein and low indigestible NDF and undegradable neutral detergent insoluble protein concentrations. Regarding digestive characteristics, macauba seeds cake was similar to soybean meal.

\section{Conclusions}

The different types of co-products and by-products can be part of ruminant animal feeding when used properly; they can also be used as protein feedstuffs. Soybean meal was the component presenting the best nutritional composition, although other products as macauba seeds cake, cottonseed meal and peanut and turnip cakes had presented good composition as well. Testing feedstuffs during in vivo evaluations is highly recommended in order to establish the possibility of whether or not to use these feedstuffs and which would be the best amount to include them.

\section{References}

AMERICAN OIL CHEMISTS' SOCIETY - AOCS. Rapid determination of oil/fat utilizing high temperature solvent extraction. 2009. Available at: http://www.ankom.com/media/documents/ CrudeFat_0504_013009.pdf. Accessed on: Nov. 17, 2009.

ABDALLA, A.L.; SILVA FILHO, J.C.; GODOI, A.R. et al. Utilização de subprodutos da indústria de biodiesel na alimentação de ruminantes. Revista Brasileira de Zootecnia, v.37, p.260-268, 2008.

ARIETA, N.F.; SILVA, J.A.; SHEN, C.G. et al. Composição bromatológica de farelo e tortas da cadeia do biodiesel. In: SIMPÓSIO INTERNACIONAL DE INICIAÇÃO CIENTÍFICA DA UNIVERSIDADE DE SÃO PAULO, 17., 2009, Pirassununga. Anais... Pirassununga: USP, 2009. 1p.

CABRAL, L.S.; VALADARES FILHO, S.C.; MALAFAIA, P.A.M. et al. Estimação da digestibilidade intestinal da proteína de alimentos por intermédio da técnica de três estádios. Revista Brasileira de Zootecnia, v.30, n.2, p.546-552, 2001.

CABRAL, L.S.; VALADARES FILHO, S.C.; DETMANN, E. et al. Taxas de digestão das frações protéicas e de carboidratos para as silagens de milho e de capim-elefante, o feno de capim-tifiton85 e o farelo de soja. Revista Brasileira de Zootecnia, v.33, n.6, p.1573-1580, 2004.

CALSAMIGLIA, S.; STERN, M.D. A three-step in vitro procedure for estimating intestinal digestion of protein in ruminants. Journal of Animal Science, v.73, p.1459-1465, 1995.

CASALI, A.O.; DETMANN, E.; VALADARES FILHO, S.C. et al. Influência do tempo de incubação e tamanho de partículas sobre os teores de compostos indigestíveis em alimentos e fezes 
bovinas obtidos por procedimento in situ. Revista Brasileira de Zootecnia, v.37, n.2, p.335-342, 2008.

DETMANN, E.; CLIPES, R.C.; COELHO DA SILVA, J.F. et al. Avaliação da proteína insolúvel em detergente ácido como estimador da fração protéica indegradável no rúmen em forragens tropicais. In: REUNIÃO ANUAL DA SOCIEDADE BRASILEIRA DE ZOOTECNIA, 41., 2004, Campo Grande. Anais... Campo Grande: Sociedade Brasileira de Zootecnia, 2004 (CD-ROM).

DETMANN, E.; MAGALHÃES, K.A.; VALADARES FILHO, S.C. et al. Desenvolvimento de um submodelo bicompartimental para estimação da fração digestível da proteína bruta em bovinos a partir da composição química dos alimentos. Revista Brasileira de Zootecnia, v.37, n.12, p.2215-2221, 2008a.

DETMANN, E.; PAULINO, M.F.; VALADARES FILHO, S.C. Avaliação de alimentos ou de dietas? Uma abordagem conceitual. In: SIMPÓSIO DE PRODUÇÃO DE GADO DE CORTE, 6., 2008, Viçosa, MG. Anais... Viçosa, MG: UFV/DZO, 2008b. p.21-52.

DETMANN, E.; VALADARES FILHO, S.C. On the estimation of non-fibrous carbohydrates in feeds and diets. Arquivo Brasileiro de Medicina Veterinária e Zootecnia, v.62, n.4, p.980-984, 2010.

FOOD AND AGRICULTURE ORGANIZATION - FAO. El estado mundial de la agricultura y la alimentación. In: Biocombustibles: perspectivas, riesgos y oportunidades. Roma: FAO, 2008. 146p.

FOX, D.G.; TEDESCHI, L.O.; TYLUTKI, T.P. et al. The Cornell Net Carbohydrate and Protein System model for evaluating herd nutrition and nutrient excretion. Animal Feed Science and Technology, v.112, p.29-78, 2004.

GOMES, F.H.T. Composição químico-bromatológica e degradação in situ de nutrientes de co-produtos da mamona e do pinhão-manso da cadeia produtiva do biodiesel. 2007. 50f. Monografia (Estágio Curricular Obrigatório) - Universidade Federal do Ceará, Fortaleza.

INTERNATIONAL ENERGY AGENCY - IEA. World energy outlook 2006. Paris: IEA, 2006. 600p.

KRISHNAMOORTHY, U.C.; MUSCATO, T.V.; SNIFFEN, C.J. et al. Nitrogen fractions in selected feedstuffs. Journal of Dairy Science, v.65, p.217- 225, 1982.

LANA, R.P. Nutrição e alimentação animal (mitos e realidades). Viçosa, MG: UFV, 2005. 344p.

LICITRA, G.; HERNANDEZ, T.M.; VAN SOEST, P.J. Standardization of procedures for nitrogen fractionation of ruminant feedstuff. Animal Feed Science and Technology, v.57, p.347-358, 1996.

MARCONDES, M.I.; VALADARES FILHO, S.C.; DETMANN, E. et al. Degradação ruminal e digestibilidade intestinal da proteína bruta de alimentos para bovinos. Revista Brasileira de Zootecnia, v.38, n.11, p.2247-2257, 2009.

McCLEARY, B.V.; GIBSON, T.S.; MUGFORD, D.C. Measurement of total starch in cereal products by amyloglucosidase $-\alpha$-amylase method: collaborative study. Journal of Association of Analytical Communities International, v.80, n.3, p.571-579, 1997.

MENEZES, D.R.; COSTA, R.G.; ARAÚJO, G.G.L. et al. Desempenho e ganho de peso de cordeiros alimentados com farelo de mamona. In: SIMPÓSIO INTERNACIONAL SOBRE CAPRINOS E OVINOS DE CORTE, 4., 2009; FEIRA NACIONAL DO AGRONÉGOCIO DA CAPRINO-OVINOCULTURA DE CORTE, João Pessoa. Anais... João Pessoa, 2009. 3p.
MOREIRA, J.F.C.; RODRIGUEZ, N.M.; FERNANDES, P.C.C et al. Concentrados protéicos para bovinos. 1. Digestibilidade in situ da matéria seca e da proteína bruta. Arquivo Brasileiro de Medicina Veterinária e Zootecnia, v.55, n.3, p.315-323, 2003.

NEIVA JÚNIOR, A.P.; VAN CLEEF, E.H.C.B. et al. Subprodutos agroindustriais do biodiesel na alimentação de ruminantes. In: CONGRESSO DA REDE BRASILEIRA DE TECNOLOGIA DE BIODIESEL, 2., 2007, Brasília, DF. Brasília: ABIPTI, 2007. Available at: http://www.biodiesel.gov.br/docs/congresso2007/ coproduto/21.pdf Accessed on: November 24, 2009

OLIVEIRA, A.S.; CAMPOS, J.M.S.; VALADARES FILHO, S.C. et al. Consumo, digestibilidade dos nutrientes e indicadores de função hepática em ovinos alimentados com dietas contendo farelo ou torta de mamona tratado ou não com hidróxido de cálcio. In: CONGRESSO DA REDE BRASILEIRA DE TECNOLOGIA DO BIODIESEL, 1., 2004. Varginha. Anais... Varginha, 2004. Available at: http://www.biodiesel.gov.br/docs/congressso2006/ Co-Produtos/Consumo2.pdf > Accessed on: Jan. 19, 2010.

SALIBA, E.O.S.; OLIVEIRA, M.C.; FARIA, E.P. et al. Avaliação da concentração de amido na raiz de genótipos de mandioca através das técnicas enzimáticas: espectroscopia no infravermelho com transformação de Fourier (FTIV) e análise particular por difração a laser (pártica). In: REUNIÃO ANUAL DA SOCIEDADE BRASILEIRA DE ZOOTECNIA, 46., 2009, Maringá. Anais.. Maringá: SBZ, 2009. (CD-ROM).

SANTOS, J.E.P. Efeitos da nutrição na reprodução. Veterinary Medicine Teaching and Research Center, School of Veterinary Medicine, UC-Davis. 1999. Available at: http://www.abcz.org.br/ site/eventos/anais/1998/24-76.doc. Accessed on: Nov. 5, 2009

SILVA, D.J.; QUEIROZ, A.C. Análise de alimentos (métodos químicos e biológicos). 3.ed. Viçosa, MG : Editora UFV, 2002. 235p.

SILVA, A.G.M.; BORGES, I.; NEIVA, J.N. et al. Degradabilidade in situ da torta de babaçu - matéria seca e proteína. In: CONGRESSO NORDESTINO DE PRODUÇÃO ANIMAL, 5. 2008, Aracaju. Anais... Aracaju, 2008a.

SILVA, J.A.; CAMPOS, F.C.; VIEIRA, S.S. et al. Análise bromatológica de co-produtos do biodiesel. In: SIMPÓSIO INTERNACIONAL DE INICIAÇÃO CIENTÍFICA DA UNIVERSIDADE DE SÃO PAULO, 16., 2008, Piracicaba, SP. Anais... Piracicaba: USP, 2008b. 1p.

SNIFFEN, C.J.; O'CONNOR, J.D.; VAN SOEST, P.J. et al. A net carbohydrate and protein system for evaluating cattle diets: II. Carbohydrate and protein availability. Journal of Animal Science, v.70, p.3562- 3577, 1992.

SOUZA, A.D.V.; FAVARO, S.P.; ÍTAVO, L.C.V. et al. Caracterização química de sementes e tortas de pinhão-manso, nabo-forrageiro e crambe. Pesquisa Agropecuária Brasileira, v.44, n.10, p.1328-1335, 2009.

TILLEY, J.M.A.; TERRY, R.A. A two-stage technique for the in vitro digestion of forage crops. Journal British Grassland Society, v.18, n.2, p.104-111, 1963.

VALADARES FILHO, S.C.; PAULINO, P.V.R.; MAGALHÃES, K.A. Exigências nutricionais de zebuínos e tabelas de composição de alimentos - BR-CORTE. Viçosa, MG: UFV, DZO, 2006. $142 p$.

VAN SOEST, P.J. Nutritional ecology of the ruminant. 2.ed. Cornell University Press, 1994. 475p. 